\title{
Thermal analysis on a weld joint of aluminium alloy in gas metal arc welding
}

\author{
Ismail, M.I.S. ${ }^{\text {a, }}{ }^{*}$, Afieq, W.M. ${ }^{a}$ \\ ${ }^{a}$ Department of Mechanical and Manufacturing Engineering, Faculty of Engineering, Universiti Putra Malaysia, Serdang, \\ 43400, Selangor, Malaysia
}

\section{A B S T R A C T}

In this paper, a three-dimensional finite element model has been developed to simulate dynamically the gas metal arc welding (GMAW) process of aluminium alloy sheets. The numerical simulation was conducted using a non-linear transient thermal analysis by changing the welding parameters: namely arc power and welding speed. A moving Gaussian distributed heat source is implemented. All major physical phenomena associated with the GMAW process, such as thermal conduction and convection heat losses are taken into account in the model development. The developed model can calculate the temperature field and predict the weld geometry profile during the welding process. The measurement of weld bead profile from the GMAW experiments was used to validate the developed finite element model. The numerical study reveals that the arc voltage and welding speed have a significant influence on the temperature distribution, weld pool size and shape, and weld bead geometry. The results show that there are good agreements with the weld bead profile between the experimental observation and finite element simulation.
\end{abstract}

\section{ARTICLE INFO}

Keywords:

Gas metal arc welding

Aluminium alloy

Weld bead profile

Finite element model

Thermal analysis

*Corresponding author:

ms_idris@upm.edu.my

(Ismail, M.I.S.)

Article history:

Received 31 August 2015

Revised 22 January 2016

Accepted 25 January 2016 


\section{References}

[1] Benyounis, K.Y., Olabi, A.G., Hashmi, M.S.J. (2005). Effect of laser welding parameters on the heat input and weldbead profile, Journal of Materials Processing Technology, Vol. 164-165, 978-985, doi: 10.1016/i.jmatprotec. 2005.02.060.

[2] Shanmugam, N.S., Buvanashekaran, G., Sankaranarayasamy, K., Kumar, S.R. (2010). A transient finite element simulation of the temperature and bead profiles of T-joint laser weld, Materials \& Design, Vol. 31, No. 9, 4528-4542, doi: 10.1016/j.matdes.2010.03.057.

[3] Talabi, S.I., Owolabi, O.B., Adebisi, J.A., Yahaya, T. (2014). Effect of welding variables on mechanical properties of low carbon steel welded joint, Advances in Production Engineering \& Management, Vol. 9, No. 4, 181-186, doi: 10.14743/ apem2014.4.186.

[4] Satheesh, M., Edwin Raja Dhas, J. (2014). Hybrid Taguchi method for optimizing flux cored arc weld parameters for mild steel, Advances in Production Engineering \& Management, Vol. 9, No. 2, 95-103, doi: 10.14743/apem2014.2.179.

[5] Anca, A., Cardona, A., Risso, A., Fachinotti, V.D. (2011). Finite element modeling of welding process, Applied Mathematical Modelling, Vol. 35, No. 2, 688-707, doi: 10.1016/i.apm.2010.07.026.

[6] Sharma, A., Arora, N., Mishra, B. (2015). Mathematical model of bead profile in high deposition welds, Journal of Material Processing Technology, Vol. 220, 65-75, doi: 10.1016/i.jmatprotec.2015.01.009.

[7] Chan, B.K.H., Bibby, M.J., Yang, L.J., Chandel, R. (1993). A discussion of algorithms for representing submerged arc weld shape with workpiece edge preparation, In: Winter Annual Meeting, Manufacturing Science and Engineering, New Orleans, USA, 873-878.

[8] Kim, G.H., Kang, S.I., Lee, S.B. (1999). A study on the estimate of weld bead shape and the compensation of welding parameters by considering weld defects in horizontal fillet welds, In: Third International Conference on Knowledge-based Intelligent Information Engineering Systems, Adelaide, Australia, 212-216, doi: 10.1109/KES.1999.820157.

[9] Datta, S., Bandyopadhyay, A., Pal, P.K. (2008). Modelling and optimization of features of bead geometry including percentage dilution in submerged arc welding using mixture of fresh flux and fused slag, The International Journal of Advanced Manufacturing Technology, Vol. 36, No. 11, 1080-1090, doi: 10.1007/s00170-006-0917-4.

[10] Ma, J., Kong, F., Kovacevic, R. (2012). Finite-element thermal analysis of laser welding of galvanized high-strength steel in a zero-gap lap joint configuration and its experimental verification, Materials \& Design, Vol. 36, 348-358, doi: 10.1016/j.matdes.2011.11.027.

[11] Ribic, B., Palmer, T.A., Debroy, T. (2009). Problems and issues in laser-arc hybrid welding, International Materials Reviews, Vol. 54, No. 4, 223-244, doi: 10.1179/174328009X411163.

[12] Uday, M., Ahmad Fauzi, M.N., Zuhailawati, H., Ismail, A.B. (2012). Thermal analysis of friction welding process in relation to the welding of YSZ-alumina composite and 6061 aluminum alloy, Applied Surface Science, Vol. 258, No. 20, 8264-8272, doi: 10.1016/j.apsusc.2012.05.035.

[13] Lindgren, L.E. (2001). Finite element modeling and simulation of welding - Part 1: Increased complexity, Journal of Thermal Stresses, Vol. 24, No. 2, 141-192, doi: 10.1080/01495730150500442.

[14] Lindgren, L.E. (2001). Finite element modeling and simulation of welding - Part 2: Improved material modeling, Journal of Thermal Stresses, Vol. 24, No. 3, 195-231, doi: 10.1080/014957301300006380.

[15] Lindgren, L.E. (2001). Finite element modeling and simulation of welding - Part 3: Efficiency and integration, Journal of Thermal Stresses, Vol. 24, No. 4, 305-334, doi: 10.1080/01495730151078117.

[16] Ueda, Y., Yamakawa, T. (1971). Analysis of thermal-elastic stress and strain during welding by finite element method, Transactions of the Japan Welding Society, Vol. 2, No. 2, 90-100.

[17] Hibbitt, H.D., Marcal, P.V. (1973). A numerical thermo-mechanical model for the welding and subsequent loading of fabricated structure, Computers \& Structures, Vol. 3, No. 5, 1145-1174, doi: 10.1016/0045-7949(73)90043-6.

[18] Goldak, J., Chakravarti, A., Bibby, M. (1984). A new finite element model for welding heat sources, Metallurgical Transactions B, Vol. 15, No. 2, 299-305, doi: 10.1007/BF02667333.

[19] Hackmair, C., Werner, E., Pönisch, M. (2003). Application of welding simulation for chassis components within the development of manufacturing methods, Computational Materials Science, Vol. 28, No. 3-4, 540-547, doi:10.1016/ j.commatsci.2003.08.011.

[20] Long, H., Gery, D., Carlier, A., Maropoulos, P.G. (2009). Prediction of welding distortion in butt joint of thin plates, Materials \& Design, Vol. 30, No. 10, 4126-4135, doi: 10.1016/i.matdes.2009.05.004.

[21] Al-Badour, F., Merah, N., Shuaib, A., Bazoune, A. (2014). Thermo-mechanical finite element model of friction stir welding of dissimilar alloys, The International Journal of Advanced Manufacturing Technology, Vol. 72, No. 5, 607617, doi: $10.1007 / \mathrm{s} 00170-014-5680-3$.

[22] Tsirkas, S.A., Papanikos, P., Kermanidis, Th. (2003). Numerical simulation of the laser welding process in butt-joint specimens, Journal of Materials Processing Technology, Vol. 134, No. 1,59-69, doi: 10.1016/S0924-0136(02)00921-4.

[23] Reed, R.C., Stone, H.J., Dye, D., Roberts, S.M., McKenzie, S.G. (2000). Process modelling of the electron beam welding of aeroengine components, In: Ninth International Symposium on Superalloys, Pennsylvania, 665-674, doi: 10.7449/ 2000/Superalloys 2000665674.

[24] Afieq, W.M. (2015). Thermal analysis of weld joint in GMAW process, Bachelor dissertation, Universiti Putra Malaysia, Malaysia.

[25] Tian, L., Luo, Y., Wang, Y., Wu, X. (2014). Prediction of transverse and angular distortions of gas tungsten arc beadon-plate welding using artificial neural network, Materials \& Design, Vol. 54, 458-472, doi: 10.1016/i.matdes. 2013.08.082.

[26] Atkins, G., Thiessen, D., Nissley, N., Adonyi, Y. (2002). Welding process effects in weldability testing of steels, Welding Journal, Vol. 81, No. 4, 61s-68s.

[27] Ismail, M.I.S., Okamoto, Y., Uno, Y. (2011). Numerical simulation on micro-welding of thin stainless steel sheet by 
fiber laser, International Journal of Electrical Machining, Vol. 16, 9-14.

[28] Yilbas, B.S., Akhtar, S., Shuja, S.Z. (2013). Laser forming and welding processes, Springer, New York, doi: 10.1007/ 978-3-319-00981-0.

[29] Ternik, P., Rudolf, R. (2014). Laminar forced convection heat transfer characteristics from a heated cylinder in water based nanofluids, International Journal of Simulation Modelling, Vol. 13, No. 3, 312-322, doi: 10.2507/ IJSIMM13(3)5.271.

[30] Ternik, P., Buchmeister, J. (2015). Buoyancy-induced flow and heat transfer of power law fluids in a side heated square cavity, International Journal of Simulation Modelling, Vol.14, No.2, 238-249, doi: 10.2507/IJSIMM14(2)5.293.

[31] Ternik, P. (2015). Conduction and convection heat transfer characteristics of water-Au nanofluid in a cubic enclosure with differentially heated side walls, International Journal of Heat and Mass Transfer, Vol. 80, 368-375, doi: 10.1016/j.ijheatmasstransfer.2014.09.041.

[32] Lin, Q., Liu, J. (2007). Counterexamples to the asymptotic expansion of interpolation in finite elements, Advances in Computational Mathematics, Vol. 27, No. 2, 167-177, doi: 10.1007/s10444-007-9030-y.

[33] Asadzadeh, M., Schatz, A.H., Wendland, W. (2009). A new approach to Richardson extrapolation in the finite element method for second order elliptic problems, Mathematics of Computation, Vol. 78, 1951-1973, doi: 10.1090/S00255718-09-02241-8.

[34] Moraitis, G.A., Labeas, G.N. (2008). Residual stress and distortion calculation of laser beam welding for aluminum lap joints, Journal of Materials Processing Technology, Vol. 198, No. 1-2, 260-269, doi: 10.1016/i.jmatprotec. 2007.07.013.

[35] Malik, A.M., Qureshi, E.M., Dar, N.U., Khan, I. (2008). Analysis of circumferentially arc welded thin-walled cylinders to investigate the residual stress fields, Thin-Walled Structure, Vol. 46, No. 12, 1391-1401, doi: 10.1016/j.tws. 2008.03.011.

[36] Mandal, N.R. (2004). Welding and distortion control, Alpha Science International Ltd, Pangbourne, England. 


\section{APEM}

\title{
Termična analiza zvarnega spoja aluminijeve zlitine pri plinskem obločnem varjenju kovin
}

\author{
Ismail, M.I.S. ${ }^{\mathrm{a},{ }^{*},}$, Afieq, W.M. ${ }^{\mathrm{a}}$ \\ aDepartment of Mechanical and Manufacturing Engineering, Faculty of Engineering, Universiti Putra Malaysia, Serdang, \\ 43400, Selangor, Malaysia
}

\section{POVZETEK}

Da bi dinamično simulirali postopek plinskega obločnega varjenja kovin (GMAW) smo razvili 3D-model s pomočjo končnih elementov. Varili smo pločevine iz aluminijeve zlitine. Numerična simulacija je bila izvedena $s$ pomočjo nelinearnega prehoda toplote ob spreminjajočih parametrih varjenja, in sicer moči obloka in hitrosti varjenja. Uporabljen je bil premikajoč vir toplote po Gaussovi porazdelitvi. Pri razvoju modela so bili upoštevani vsi glavni fizikalni pojavi, ki so povezani s postopkom GMAW, in sicer prenos toplote in toplotne izgube zaradi konvekcije. Razvit numerični model lahko izračuna temperaturno polje in napove geometrijo profila zvarnega spoja med varjenjem. Da bi potrdili uspešnost modela, smo izvedli tudi meritve profila varka med izvedenimi eksperimenti varjenja po metodi GMAW. Numerična študija je razkrila, da imata napetost obloka in hitrost varjenja pomemben vpliv na porazdelitev temperature, na velikost in obliko bazenčka raztopljene kovine ter na geometrijo varka. Raziskava je pokazala, da smo za geometrijo profila varka dosegli dobro ujemanje eksperimentalnih opažanj z rezultati, dobljenimi s simulacijo.

\section{PODATKI O ČLANKU}

Ključne besede:

Plinsko obločno varjenje kovin

Aluminijeva zlitina

Profil varka

Končni elementi

Termična analiza

* Kontaktna oseba: ms_idris@upm.edu.my

(Ismail, M.I.S.)

Zgodovina članka:

Prejet 31. avgusta 2015

Popravljen 22. januarja 2016

Sprejet 25. januarja 2016 